\title{
Population structure analysis of Pimelodus maculatus (Pisces, Siluriformes) from the Tietê and Paranapanema Rivers (Brazil)
}

\author{
Fernanda Simões de Almeida ${ }^{1}$, Leda Maria Koelblinger Sodré ${ }^{2}$ and Eucleia Primo Betioli Contel ${ }^{1}$ \\ ${ }^{1}$ FMRP-USP, Departamento de Genética, Ribeirão Preto, São Paulo, Brazil. \\ ${ }^{2}$ UEL, Departamento de Biologia Geral, Londrina, Paraná, Brazil.
}

\begin{abstract}
Pimelodus maculatus populations from the Tietê and Paranapanema rivers were sampled and had their genetic structure analyzed by using RAPD markers, with the aim of contributing to future conservation studies. The proportion of polymorphic loci was greater than $50 \%$ in the populations of both rivers. Genetic diversity data showed that, in spite of its nine hydroelectric plants, the Tietê river population was genetically homogeneous, whereas the Paranapanema river population was structured. This might be due to the presence of high waterfalls distributed all along its course. These data may serve as indicators for future conservation studies on the Tietê and Paranapanema rivers.
\end{abstract}

Key words: RAPD markers, population structure, conservation, genetic variability, Pimelodus.

Received: October 10, 2002; Accepted: May 5, 2003.

\section{Introduction}

The biodiversity of our planet has suffered severe modifications with the increase in human population and industrial development. Human activity presently consumes $40 \%$ of all its land-based primary production . Fish and other marine organisms are the only wild animals consumed on a large scale by our species, by direct exploitation of natural populations (Solé-Cava, 2001).

The construction of hydroelectric plants destroys habitats and increases the geographic fragmentation of many fish species. Reduction in the genetic flow may even change the ratio of components of diversity between and within populations (Vrijenhoek, 1998).

Knowledge of the effects of genetic variability on fish distribution is of fundamental importance to understand how diversity is distributed among populations, that is, the relative degree of diversity within populations and among them. Genetic methods for fish management, conservation and rearing, for example, depend on knowledge of the variation within a local reproductive unit (Carvalho, 1993).

Among the Siluriformes, the Pimelodidae family, to which the genus Pimelodus belongs, is the second largest

Send correspondence to Eucleia Primo Betioli Contel. Universidade de São Paulo, Faculdade de Medicina de Ribeirão Preto, Departamento de Genética, Av. Bandeirantes 3900, 14049-900 Ribeirão Preto, São Paulo, SP, Brazil. E-mail: epbconte@rge.fmrp. usp.br. and one of the most diverse. It is found throughout Central and South America (Burgess, 1989). Genus Pimelodus is considered to be a complex, where taxonomy of species and populations similar to the type-species Pimelodus maculatus is not well-established at the species level. The genus has not yet been organized in a conclusive phylogenetic tree (Lundberg et al., 1991).

The objective of this study was to analyze Pimelodus maculatus populations of the Tietê and Paranapanema rivers, in the States of São Paulo (SP) and Paraná (PR), to obtain data on their genetic structure that may contribute to conservation studies.

\section{Material and Methods}

P. maculatus specimens were collected at three sites of each river. On the Tietê, collections were made in the lower reaches at Araçatuba (SP), in the middle at Barra Bonita (SP), and in the upper river at Cerquilho (SP). On the Paranapanema river, collections were made from the lower, middle, and upper river at Taquarauçu (SP), Porecatu (PR), and Paranapanema (SP), respectively. Ten individuals from each location were used for analysis.

Muscle samples were removed from specimens immediately after capture and kept at $-20{ }^{\circ} \mathrm{C}$ until use. The specimens used in this study were preserved and registered by the Zoology Museum of the State University at Londrina. 


\section{DNA extraction and random amplified polymorphic DNA (RAPD) analysis}

DNA was extracted from the muscle, following the procedure described by Almeida et al. (2001). Forty different 10-mer oligonucleotides (kits OPW and OPAM from Operon Technologies Ltd.) were used as random primers in the RAPD screening, and 15 were selected based on the number of bands obtained and on their ability to produce consistent fragment patterns. Amplification reactions were performed in a total volume of $15 \mu \mathrm{L}$ containing $10-15 \mathrm{ng}$ of template DNA, $0.25 \mu \mathrm{mol}$ primer, $3.5 \mathrm{mM} \mathrm{MgCl}_{2}$, $250 \mu \mathrm{mol} \mathrm{dNTP}$, and 1 unit of Taq DNA polymerase (Biotools) in the reaction buffer supplied. Control reactions were run containing all components except genomic DNA. Reactions were performed in a PTC-100 thermal cycler (MJ Research), during 40 cycles of $40 \mathrm{~s}$ at $92{ }^{\circ} \mathrm{C}, 90 \mathrm{~s}$ at $40{ }^{\circ} \mathrm{C}$, and $120 \mathrm{~s}$ at $72{ }^{\circ} \mathrm{C}$, after an initial denaturation of 5 min at $92{ }^{\circ} \mathrm{C}$. Finally, one cycle of $5 \mathrm{~min}$ at $72^{\circ} \mathrm{C}$ was performed.

The RAPD products were resolved by electrophoresis at $3 \mathrm{~V} \cdot \mathrm{cm}^{-1}$ in $1.4 \%$ agarose gels, run with TBE buffer (0.89 M Tris, 0.89 M boric acid, and 2 mM EDTA pH 8.3) diluted 1:10 (v:v). Gels were stained with ethidium bromide and photographed under ultraviolet light using T-Max Kodak film.

\section{Data analysis}

Comparative analysis was carried out by placing on the same gel samples from all ten individuals from each site of the same river, for intra- and inter-population analysis. The RAPD marker profiles were determined by direct comparison of the amplified DNA electrophoresis profiles, and the data obtained were analyzed as binary variables (band presence or absence). Each band was considered to be an allele of a locus, and genetic diversity was estimated in the informal sense, since it seems likely that fragments amplified by arbitrary primers frequently contain uncoded regions (Lynch and Milligan, 1994).
Genetic variability was estimated via the proportion of polymorphic loci $(\overline{\mathrm{P}})$, Nei's (1973) measure of genetic diversity $\left(\mathrm{G}_{S T}\right)$, and the gene flow among the populations, which is equivalent to the number of migrants per generation $(\mathrm{Nm})$, using the genetic analysis package POPGENE 1.31 (Yeh et al. 1999). Fisher's exact test, used to test differences in the marker frequencies among the different populations, and calculation of Nei's (1978) unbiased genetic identity (I), using the Lynch and Milligan (1994) frequency correction for dominant markers, were carried out with the TFPGA 1.3 software (Miller, 1997). The significance values were corrected by applying the Bonferroni procedure. Genetic similarity dendrograms among the populations of each river were constructed by using the Jaccard (J) coefficient and the UPGMA grouping method in the computer program NTSYS-PC (Rohlf, 1992).

\section{Results and Discussion}

The presence of variability within species (among populations, and also between individuals within populations) is essential to their ability to survive and to successfully respond to environmental changes (Ryman et al., 1995). A total of 210 loci was obtained for P. maculatus in the Tietê river by analyzing the 15 primers, and the number of fragments per primer ranged from 6 to 19 . The proportions of polymorphic loci estimated for the lower, the middle and the upper Tietê river were $60.19 \%, 51.94 \%$, and $52.43 \%$, respectively.

No significant difference in marker frequencies was detected between the subpopulations of the lower, middle and upper Tietê river by Fisher's exact test (Table 1). The $\mathrm{G}_{S T}$ variable was not significant among the subpopulations of the Tietê river. The estimated gene flow $(\mathrm{Nm})$ was 6.4809 between the lower and the middle Tietê, 4.5967 between the lower and the upper Tietê, and 4.3327 between the middle and the upper Tietê populations (Table 1).

One of the problems of population structure analysis is to estimate the amount of gene flow, which is the most important determinant of the population structure, because

Table 1 - Genetic diversity among populations $\left(\mathrm{G}_{S T}\right)$, mean number of migrants per generation $(\mathrm{Nm})$, and Fisher's exact test for the Pimelodus maculatus populations in the Tietê and Paranapanema rivers. LT = Lower Tietê river, MT = middle Tietê river, UT = upper Tietê river, LP $=$ lower Paranapanema river, $\mathrm{MP}=$ middle Paranapanema river, and UP = upper Paranapanema river

\begin{tabular}{|c|c|c|c|c|c|c|c|}
\hline & \multicolumn{3}{|c|}{$\mathrm{G}_{S T}$} & \multirow[b]{2}{*}{$\mathrm{Nm}$} & \multicolumn{3}{|c|}{ Fisher's exact test } \\
\hline & $\mathrm{G}_{S T}$ & $\chi^{2}$ & $\mathrm{P}(\mathrm{gl}=1)$ & & $\chi^{2}$ & $\mathrm{gl}$ & $\mathrm{P}$ \\
\hline $\mathrm{LT} / \mathrm{MT}$ & 0.0716 & 2.864 & $>0.05$ & 6.4809 & 156.9805 & 412 & $>0.05$ \\
\hline LT/UT & 0.0981 & 3.924 & $>0.05$ & 4.5967 & 190.8310 & 412 & $>0.05$ \\
\hline $\mathrm{MT} / \mathrm{UT}$ & 0.1035 & 4.140 & $>0.05$ & 4.3327 & 201.4722 & 412 & $>0.05$ \\
\hline LP/MP & 0.1007 & 4.028 & $>0.05$ & 4.4646 & 212.1281 & 478 & $>0.05$ \\
\hline LP/UP & 0.1870 & 7.480 & $*$ & 2.1732 & 555.9281 & 478 & * \\
\hline MP/UP & 0.2103 & 8.412 & * & 1.8776 & 587.6500 & 478 & * \\
\hline
\end{tabular}

* statistically significant at the $5 \%$ level, corrected for 3 non-independent multiple tests by the Bonferroni procedure. 
it determines to which extent each local population of a species is an independent evolutionary unit (Slatkin, 1993). So, if gene flow among nearby populations is intense, they evolve together, while, if it is small, each population evolves in a virtually independent manner.

The genetic identity values ranged from 0.9544 between the lower and upper Tietê to 0.9718 between the lower and middle Tietê (Table 2). The genetic identity values observed among the three locations were in line with the expected values for individuals of the same population, according to Thorpe and Solé-Cava (1994), who found that $98 \%$ of populations of the same species (co-specific) have a genetic identity over 0.85 .

The joint analysis of the genetic diversity, gene flow, and genetic identity data indicated that the $P$. maculatus population of the Tietê river was homogeneous.

The analysis of the RAPD marker profiles for $P$. maculatus from the Tietê river showed the presence of a single group. The dendrogram shows that the individuals from the three locations are mixed together (Figure 1). According to Vazzoler et al. (1997), P. maculatus is a medium-sized species, about 20 to $40 \mathrm{~cm}$ long, and considered a great migrant. The dendrogram shows the clustering pattern expected for a migratory species, where no separation of the individuals in subpopulations is observed.

Table 2 - Nei's genetic identity (1978), corrected by the Lynch and Milligan (1994) procedure, for Pimelodus maculatus populations of the Tietê river.

\begin{tabular}{lccc}
\hline Subpopulations & LT & MT & UT \\
\hline LT & $* * * *$ & & \\
MT & 0.9718 & $* * * *$ & \\
UT & 0.9544 & 0.9563 & $* * * *$ \\
\hline
\end{tabular}

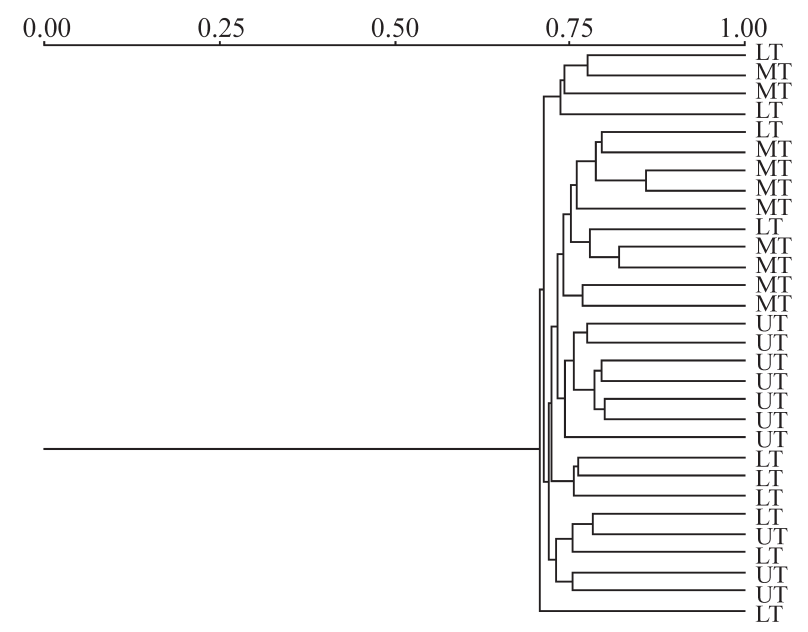

Figure 1 - Dendrogram constructed using the Jaccard coefficient and the UPGMA method for Pimelodus maculatus from the Tietê river. $\mathrm{LT}=$ Lower Tietê, $\mathrm{MT}=$ Middle Tietê, and $\mathrm{UT}=$ Upper Tietê .
Altogether, there are nine hydroelectric plants from the upper to the lower Tietê, where the water drops more than $10 \mathrm{~m}$. In spite of these reservoirs, the presence of locks to make the Tietê river navigable must allow migration of this species, as the data reported here indicate that the subpopulations from the lower, middle and upper Tietê river are genetically very similar.

In the P. maculatus samples from the Paranapanema river, the 15 primers produced a total of 239 loci, and the number of fragments ranged from 8 to 23 . The proportion of polymorphic loci obtained was $56.49 \%, 54.81 \%$, and $61.51 \%$ for the lower, middle and upper Paranapanema, respectively. The polymorphism values found were similar to those obtained for Pimelodus maculatus from the Tietê river.

The genetic diversity between populations $\left(\mathrm{G}_{S T}\right)$ was significant for the pairs of subpopulations of the lower and upper, and the middle and upper Paranapanema (Table 1). Just like $\mathrm{G}_{S T}$, Fisher's exact test showed a less-thansignificant difference only between the lower and the middle Paranapanema samples (Table 1). This indicates that there is genetic differentiation between the upper Paranapanema subpopulation and those of the lower and middle parts, and a greater similarity between the lower and middle Paranapanema subpopulations.

According to Wright (1978), $\mathrm{G}_{S T}$ estimates with probabilities between 0.05 and 0.15 are considered indicative of moderate population structuring, and with probabilities between 0.15 and 0.25 of high population structuring. Therefore, the P. maculatus population of the Paranapanema river was found to be moderately structured between the lower and middle subpopulations, and highly structured between the lower and upper, and between the middle and upper Paranapanema subpopulations.

Structured populations usually show a dynamic equilibrium between factors which favor differentiation (mutation, drift, and directional or disruptive natural selection, differing in each area) and homogenizing factors (migration, purifying natural selection, and balanced or differential natural selection, uniform in each area) (Solé-Cava, 2001).

The gene flow estimates for $P$. maculatus in the Paranapanema river were $4.4646,2.1732$, and 1.8776 between the lower and middle, lower and upper, and middle and upper parts, respectively (Table 1). The population genetic parameter $\mathrm{Nm}$, which measures the number of migrants per generation, also provides an indication of the differentiation among populations. Thus, although the $\mathrm{Nm}$ values were above 1 , indicating gene flow action against genetic differentiation among the populations, the actual gene flow between the upper Paranapanema subpopulation and the subpopulations of the lower and middle parts was not strong enough to prevent the genetic differentiation detected by Fisher's exact test and $\mathrm{G}_{S T}$. 
The observed genetic identity values were 0.9537 between the lower and middle, 0.8919 between the lower and upper, and 0.8772 between the middle and upper Paranapanema subpopulations (Table 3). Together with the other genetic parameters, they confirmed the considerable genetic differentiation between the upper Paranapanema subpopulation and those of the lower and middle parts, as well as the homogeneity across the lower and middle Paranapanema subpopulations.

Analysis of the RAPD marker profiles obtained for the $P$. maculatus samples from the Paranapanema river pointed to a certain degree of differentiation between individuals from the upper and individuals from the lower and middle parts of the river (Figure 2). The dendrogram shows the formation of two clusters, one consisting of individuals from the lower and middle Paranapanema, and the other of those from the upper river. Individuals from the lower and the middle Paranapanema showed a tendency to separate into clusters, according to their original location (Figure 3).

Sampaio (1944) reported on an expedition to the Itapetininga and Paranapanema rivers made in 1889 that found many waterfalls on the Paranapanema river, some of them over $60 \mathrm{~m}$ high. Nowadays, there are six hydroelectric plants on that river, for which dams were built on its many

Table 3 - Nei's genetic identity (1978), corrected by the Lynch and Milligan (1994) procedure, for Pimelodus maculatus populations of the Paranapanema river.

\begin{tabular}{lccc}
\hline Subpopulations & LP & MP & UP \\
\hline LP & $* * * *$ & & \\
MP & 0.9537 & $* * * *$ & \\
UP & 0.8919 & 0.8772 & $* * * *$ \\
\hline
\end{tabular}

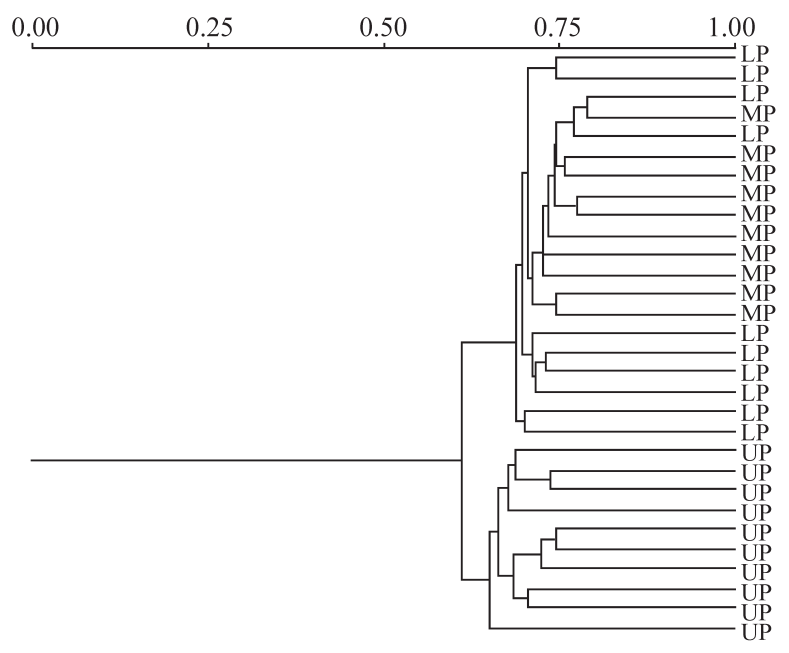

Figure 3 - Dendrogram constructed using the Jaccard coefficient and the UPGMA method for Pimelodus maculatus in the Paranapanema river. LP $=$ Lower Paranapanema, MP = Middle Paranapanema, and UP $=$ Upper Paranapanema.

waterfalls. Thus, it seems likely that there were already barriers to gene flow between the sites on the lower, middle and upper Paranapanema river, before the construction of the hydroelectric plants, explaining the genetic differentiation data found in this study.

The process of dam construction and consequent reservoir formation leads to changes in the physical, chemical, sanitary, and biological characteristics of a river. Therefore, the current Brazilian environmental laws require that corporations responsible for a dam propose a conservation program for aquatic organisms. Fish rearing in captivity for river re-population may be a helpful tool for conservation of the native fish fauna of the Brazilian river basins, espe-

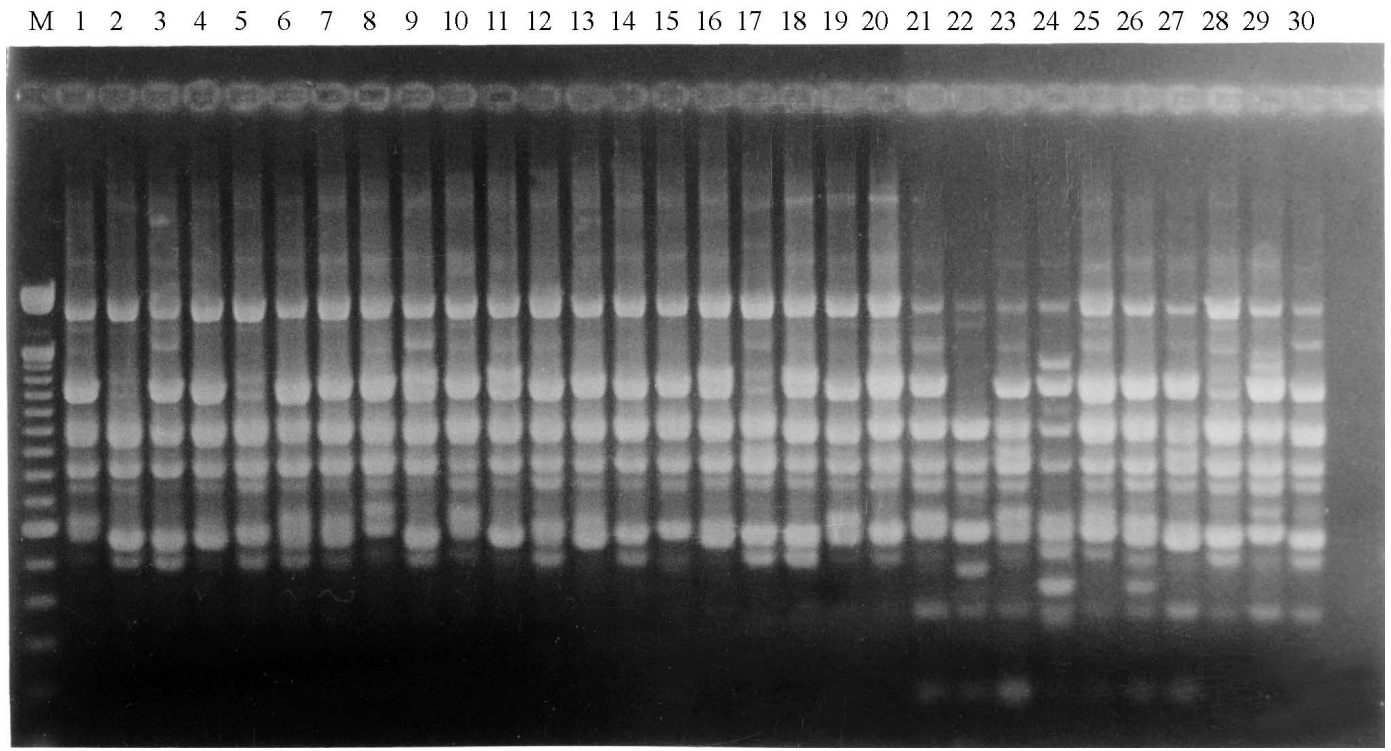

Figure 2 - DNA polymorphism of Pimelodus maculatus from the Paranapanema river, amplified with primer OPW20. Column M=50 bp molecular weight marker. Columns 1 to $10=$ Lower Paranapanema (LP); Columns 11 to $20=$ Middle Paranapanema (MP); Columns 21 to $30=\mathrm{Upper}$ Paranapanema (UP). 
cially in cases of imminent risk of extinction. However, its use as an environmental recovery strategy should be reviewed, as it is not advisable and has already caused irreparable damage to the environment (Vieira and Pompeu, 2001).

Conservation studies are very important and, whenever an endangered species that occupies a certain area is structured, conservation strategy should aim at preserving its diversity in that area, as there may already be local adaptation that will be lost if the population is mixed with others. On the other hand, if the population of a species is homogeneous throughout the region where it is found, then it is recommended to concentrate protection of this species on a single area, using individuals from this area to recolonize the others when necessary (apud Haig, 1998).

In the present study, two distinct situations were observed that should be taken into account in the context of conservation. In the Tietê river, the population was homogeneous throughout the area of occurrence of the species. It would therefore be advisable, if necessary, to concentrate its protection on a single area, and to use individuals from that area to re-colonize the river. The results obtained from the Paranapanema samples, however, showed that this river has a structured population. Therefore, any conservation strategy should attempt to preserve the difference between the lower/middle and upper Paranapanema river subpopulations. Any local adaptation would be lost if these subpopulations were mixed.

\section{Acknowledgments}

The authors thank Dr Oscar Akio Shibatta and MS Mário Luís Orsi from the Universidade Estadual de Londrina for collection and identification of the specimens. We also thank FAPESP (Fundação de Amparo à Pesquisa do Estado de São Paulo) for financial support.

\section{References}

Almeida FS, Fungaro MHP and Sodré LMK (2001) RAPD and isoenzyme analysis of genetic variability in three allied species of catfishes (Siluriformes: Pimelodidae) from the Tibagi river, Brazil. J Zool 253:113-120.

Burgess WE (1989) An Atlas of freshwater and marine catfishes. A preliminary survey of the Siluriformes. T.F.H. Publications Neptune City, N.Y. 784 pp.

Carvalho GR (1993) Evolutionary aspects of fish distribution: genetic variability and adaptation. J Fish Biol 43(Suppl. A):53-73.
Haig SM (1998) Molecular contributions to conservation. Ecology 79:413-425.

Lundberg JG, Mago-Leccia F and Nass P (1991) Exallodontus aguanai, a new genus and species of Pimelodidae (Pisces: Siluriformes) from deep river channels of South-America, and delimitation of the subfamily Pimelodinae. Proc Biol Soc 104:840-869.

Lynch M and Milligan BG (1994) Analysis of population structure with RAPD markers. Mol Ecol 3:91-99.

Miller MP (1997) Tools for population genetic analyses (TFPGA) 1.3: A Windows program for the analysis of allozyme and molecular population genetic data. Computer software distributed by author.

Nei M (1973) Analysis of gene diversity in subdivided populations. Proc Nat Acad Sci USA 70:3321-3323.

Nei M (1978) Estimation of average heterozygosity and genetic distance from a small number of individuals. Genetics 89:583-590.

Rohlf FJ (1992) NTSYS-pc. Numerical taxonomy and multivariate analysis systems. Exeter Software, Applied Biostatistics, N.Y., $225 \mathrm{pp}$.

Ryman N, Utter F and Laikre L (1995) Protection of intraspecific biodiversity of exploited fishes. Review Fish Biol Fish 5:417-446.

Sampaio T (1944) Relato sobre os estudos efetuados nos rios Itapetininga e Paranapanema. Rev. Instituto Geográfico e Geológico 2(3):30-81.

Slatkin M (1993) Gene flow and population structure. In: Real LA (ed) Ecological genetics. Princeton University Press, pp 3-17.

Solé-Cava AM (2001) Biodiversidade molecular e genética da conservação. In: Matioli SR (ed) Biologia Molecular e Evolução. Holos, Ribeirão Preto-SP, pp 172-192.

Thorpe JP and Solé-Cava AM (1994) The use of allozyme electrophoresis in invertebrate systematics. Zool Scripta 23:3-18.

Vazzoler AEAM, Susuki HI, Marques EE and Lizama MLAP (1997) Primeira maturação gonadal, períodos e áreas de reprodução. In: Vazzoler AEAM, Agostinho AA and Hahn NS (eds) A planície de inundação do alto rio Paraná. Aspectos físicos, biológicos e socioeconômicos. EDUEM, Maringá, pp 249-265.

Vieira F and Pompeu PS (2001) Peixamento, uma alternativa eficiente? Ciência Hoje 30:28-33.

Vrijenhoek RC (1998) Conservation genetics of freshwater fish. J Fish Biol 53(Suppl. A):394-412.

Wright S (1978) Evolution and genetics of populations. Vol. 2: The theory of gene frequencies. University of Chicago Press, London. 511 pp.

Yeh FC, Boyle T, Ye Z and Xiyan JM (1999) POPGENE Version 1.31: Microsoft Windows-based freeware for population genetic analysis. University of Alberta and Center for International Forestry Research.

Editor: Yatiyo Yonenaga-Yassuda 